\title{
Recent patent applications in drug discovery automation
}

\begin{tabular}{ll} 
Patent \# & Subject \\
\hline JP 2008020275 & $\begin{array}{l}\text { An automatic solid phase extractor consisting of a vibration } \\
\text { excitation device that provides vibration to a container filled } \\
\text { with liquid, such as a pharmaceutical liquid; for use during } \\
\text { drug discovery screening. }\end{array}$
\end{tabular}

WO 2007148130 A de novo iterative synthesis method for drug discovery that selects a compound having the desired pharmacophoric fit with a seed structure and synthesizing, assaying and comparing the compound to the structure to determine whether the compound has synthetically desirable properties.

EP 1859866 US 20070274871

A well plate of non-unitary construction with side walls containing surface energy that provides a specific contact angle for aqueous solution contained in the well in an ambient environment to suppress meniscus formation; for growing cells and handling liquid samples in fields such as gene sequencing, combinatorial chemistry, drug discovery and proteomics, in automated and integrated systems.

US 7292263

A robotic charge coupled device microscope for crystal recognition with a lighting system comprising a cluster of high brightness white LEDs; useful in structural, rational drug discovery, etc.

JP 2007161453 An automatic storage apparatus for use in a drug discovery research environment, with a hand plate that moves in contact with the surrounding walls of the storage rack to obtain positional information of the storage rack in all directions.

WO 2006036737, A high-throughput, completely automated method of idenUS 20060094059, tifying a new therapeutic use for a test entity, e.g., a drug EP 1797427 or drug candidate, involving testing the activity of the test entity against a protein complex in a cell and using the results obtained to identify new activity of the test entity; useful for large-scale drug discovery.

JP 2007046956

A dispensing apparatus comprising a chip remover arranged at the back of the dispensing mechanism to remove the used chip from the dispensing head and a chip holder to hold the unused chip; useful for drug discovery.

WO 2006133555, A system for testing the psychotropic activity of a compound US 20060292549 comprising a silicon die having a surface for the growth of a neuronal network; useful for the automated screening of a compound in the field of drug discovery and neuroscience.

EP 1653235 A method of controlling the usage of reservoirs in a liquid handling area of an automated liquid handling system, involving determining and removing the content of a reservoir where the reagent is not expected to be used within a predetermined time interval; useful in drug discovery and development.

JP 2005348615 A sample thawing apparatus that uses a sequence of several acicular nozzles to eject warm water to thaw a sample sealed in a container, such as deep-well plates or microtubes; for use in drug discovery research.

\begin{tabular}{|c|c|c|c|}
\hline Assignee(s) & Inventor(s) & $\begin{array}{l}\text { Priority } \\
\text { application date }\end{array}$ & $\begin{array}{l}\text { Publication } \\
\text { date }\end{array}$ \\
\hline Hitachi Koki (Tokyo) & Toi H & $7 / 12 / 2006$ & $1 / 31 / 2008$ \\
\hline $\begin{array}{l}\text { Cresset Biomolecular } \\
\text { Discovery } \\
\text { (Letchworth, UK), } \\
\text { Cresset Therapeutics } \\
\text { (Philadelphia, PA, USA) }\end{array}$ & $\begin{array}{l}\text { Mackay M, } \\
\text { Vinter J, } \\
\text { Warrington B }\end{array}$ & 6/19/2006 & $12 / 27 / 2007$ \\
\hline $\begin{array}{l}\text { Genetix } \\
\text { (New Milton, UK) }\end{array}$ & Jiang $Y$ & 5/23/2006 & $\begin{array}{l}11 / 28 / 2007 \\
11 / 29 / 2007\end{array}$ \\
\hline
\end{tabular}

University of California $\quad$ Segelke BW, $\quad 3 / 16 / 2005 \quad 11 / 6 / 2007$

(Oakland, CA, USA)

Toppani D

Tsubakimoto Chain Co. Oshimo J, 12/15/2005 6/28/2007

(Osaka, Japan)

Shibata N

$\begin{array}{lll}\text { Odyssey Thera } & \text { MacDonald ML, 9/22/2004 } & \text { 4/6/2006, } \\ \text { (San Ramon, CA, USA) } & \text { Michnick SW, } & \text { 5/4/2006, } \\ & \text { Owens S, } & 6 / 20 / 2007\end{array}$

$\begin{array}{lll}\text { Odyssey Thera } & \text { MacDonald ML, 9/22/2004 } & \text { 4/6/2006, } \\ \text { (San Ramon, CA, USA) } & \text { Michnick SW, } & \text { 5/4/2006, } \\ & \text { Owens S, } & 6 / 20 / 2007\end{array}$

Westwick JK

Yu H

Juki Corp. (Tokyo)

Okubo K

$8 / 8 / 2005$

2/22/2007

Neurosilicon

Colicos MA

$6 / 15 / 2005$

$12 / 21 / 2006$

(Calgary, Canada)

$12 / 28 / 2006$

\section{Automation}

Grant PS,

10/27/2004

$5 / 3 / 2006$

Partnership Cambridge

Oakeshott RBS

(Royston, UK)

Tsubakimoto Chain Co.

Oshimo J

$6 / 8 / 2004$

$12 / 22 / 2005$

(Osaka, Japan)

Shibata $\mathrm{N}$,

Komada M

Source: Thomson Scientific Search Service. The status of each application is slightly different from country to country. For further details, contact Thomson Scientific, 1800 Diagonal Road, Suite 250, Alexandria, Virginia 22314, USA. Tel: 1 (800) 337-9368 (http://www.thomson.com/scientific). 